\title{
Lysiphlebus orientalis (Hymenoptera, Braconidae), a new invasive aphid parasitoid in Europe - evidence from molecular markers
}

\author{
Andjeljko Petrović ${ }^{*}$, Milana Mitrović ${ }^{2}$, Petr Starý $^{3}$, \\ Olivera Petrović-Obradović ${ }^{4}$, Vladimir Žikićs \\ Željko Tomanović ${ }^{1}$ and Christoph Vorburger ${ }^{6}$
}

${ }^{1}$ Institute of Zoology, Faculty of Biology, University of Belgrade, Studentski trg 16, 11000 Belgrade, Serbia: ${ }^{2}$ Department of Plant Pests, Institute for Plant Protection and Environment, Banatska 33, Zemun, Serbia: ${ }^{3}$ Laboratory of Aphidology, Institute of Entomology, Biology Centre, Academy of Sciences of the Czech Republic, Branišovská 31, 37005 České Budějovice, Czech Republic: ${ }^{4}$ Department of Plant Protection, Faculty of Agriculture, University of Belgrade, Nemanjina 6, 11081 Zemun, Serbia: ${ }^{5}$ Department of Biology and Ecology, Faculty of Sciences and Mathematics, University of Niš, Višegradska 33, 18000 Niš, Serbia: ${ }^{6}$ Institute of Integrative Biology, ETH Zürich, Switzerland, and EAWAG, Swiss Federal Institute of Aquatic Science and Technology, Überlandstrasse 133, 8600 Dübendorf, Switzerland

\begin{abstract}
We report the occurrence of Lysiphlebus orientalis in Serbia, an aphid parasitoid from the Far East that is new to Europe and has the potential to become invasive. Our finding based on morphological characters is confirmed by analyses of mitochondrial cytochrome oxidase subunit I sequences. An increase in number and an expansion of the host range were observed during field studies over the past two years, and it is determined that the current host range encompasses nine aphid hosts on 12 different host plants, forming 13 tri-trophic associations. A host range determined for European populations of L. orientalis appears wider compared with that in its Far Eastern native habitats where Aphis glycines Mats. is the sole known host. Moreover, it overlaps considerably with the host ranges of European parasitoids that play an important role in the natural control of pest aphids.
\end{abstract}

Keywords: new invasive species, Serbia, DNA barcoding, biological control, parasitoid

(Accepted 17 January 2013; First published online 1 March 2013)

\section{Introduction}

Non-native arthropods abound worldwide and many cause substantial ecological and economic damage (Hallman

*Author for correspondence

Phone: +381 112638890

Fax: +381 112638500

E-mail: andjeljko@bio.bg.ac.rs
\& Schwalbe, 2002). While invasions of herbivorous pest arthropods are typically the consequence of unintentional introductions, predators and parasitoids of pest arthropods are often introduced deliberately for biological control. Nevertheless, there are numerous cases of alien arthropod predators and parasitoids that became invasive and have undesirable effects on the invaded ecosystems (Roy et al., 2011). Here we report the case of an accidentally introduced parasitoid of aphids in Europe that appears to be expanding its host range. 
The subfamily Aphidiinae (Hymenoptera, Braconidae) consists of solitary endoparasitoids of aphids, several of which are of great value in pest aphid control (Hagvar \& Hofsvang, 1991, Brewer \& Elliott, 2004) and are commercially available as biocontol agents (Boivin et al., 2012). More than 200 species have been recorded in Europe (van Achterberg, 2011), but there is variation in how comprehensively the fauna of Aphidiinae is documented in different areas/countries. With 100 recorded species, Serbia is one of the most extensively surveyed European countries (Petrović et al., 2009, Petrović et al., 2011). The genus Lysiphlebus Förster, with about 30 known species, belongs to a taxonomically and biologically less studied genera (Mackauer, 1961; Kambhampati et al., 2000). It comprises highly specialized species such as L. hirticornis Mackauer which parasitize Metopeurum fuscoviride exclusively (Nyabuga et al., 2009), as well as relative generalists such as a $L$. testaceipes $(\mathrm{Cr}$.) with a host range of more than 50 species in Europe (Starý et al., 2004) and even more in its native home, North America (Pike et al., 2000). An important characteristic of the genus Lysiphlebus is the occurrence of species that have sexual and asexual reproduction such as $L$. fabarum, L. confusus and $L$. cardui (summarized in Sandrock et al., 2011).

Aphidiinae parasitoids have been used in biological control programs against pest aphids on various crops worldwide (Hagvar \& Hofsvang, 1991). Although new biocontrol agents are typically subject to a risk assessment prior to their field release, post-release studies often focus on establishment success and target effects, paying less attention to the effects of introduced parasitoids on non-target hosts. However, the best example on how important the latter studies are is L. testaceipes, a biocontrol agent introduced to Mediterranean Europe from Cuba to control Aphis citricola and Toxoptera aurantii in citrus crops. Within less than three decades L. testaceipes expanded its host range to 50 different aphid species (Cecilio, 1994; Starý et al., 1988, 2004), replacing native parasitoid species. In 2008, L. testaceipes was removed from the positive list of biocontrol agents in Europe by the European Plant Protection Organization (EPPO 2008-03-26/28).

Lysiphlebus orientalis Starý \& Rakhshani was recently described from northeast China as a specialized parasitoid of the soybean aphid (Aphis glycines Matsumura) on Glycine $\max (\mathrm{L}$.). On the basis of field-collected material and laboratory rearing, Starý et al. (2010) determined that this parasitoid occurs in all-female populations that reproduce by thelytokous parthenogenesis. Since the soybean aphid has become a major source of economic loss for soybean production in North America (Heimpel et al., 2010; Ragsdale et al., 2011), L. orientalis is currently under investigation as a potential biocontrol agent (Starý et al., 2010; Ragsdale et al., 2011). In their description of L. orientalis, Starý et al. (2010) determined on the basis of morphological characters that some Lysiphlebus specimens found recently in Europe may be related to L. orientalis. Here we present molecular evidence that L. orientalis is indeed present in Europe, presumably due to an accidental introduction. It was collected repeatedly in Serbia and it appears to be spreading geographically as well as expanding its host range.

\section{Materials and methods}

\section{Collecting}

For the past two decades, members of Lysiphlebus were intensively collected throughout Serbia as a part of ongoing research on Aphidiinae fauna. Plant samples infested with live and mummified aphids were collected in the field and transferred into plastic containers covered with nylon mesh. Voucher specimens of live aphids from each plant sample were preserved in $70 \%$ ethanol for later identification. The remaining aphids were maintained in the laboratory until parasitoid emergence.

The external morphology of emerged parasitoids was studied using a ZEISS Discovery V8 stereomicroscope. All materials used in this study are deposited in the collection of the Institute of Zoology, Faculty of Biology, University of Belgrade.

\section{DNA extraction, polymerase chain reaction (PCR) amplification and sequencing}

Thirty-five Lysiphlebus specimens were used for the molecular confirmation of species status and for the analysis of genetic variability (table 1 ). L. orientalis was represented with 22 specimens originating from Serbia and five from China. We also obtained sequences from two specimens of $L$. testaceipes and three specimens of L. balcanicus. Both species are members of the 'testaceipes' group which is closely related to L. orientalis. In addition to members of the 'testaceipes' group, we sequenced three specimens of L. fabarum which shares aphid hosts with L. orientalis. Prior to DNA extraction, all specimens were stored in $96 \%$ ethanol at $-20^{\circ} \mathrm{C}$. DNA was extracted from each individual adult wasp using the KAPA Express Extract kit (Kapa Biosystems) following the manufacturer's instructions. A region of approximately $710 \mathrm{bp}$ of the barcoding region of the mitochondrial cytochrome oxidase subunit I (COI) gene was amplified using the primers LCO1490 (5'GGTCAACAAATCATAAAGATATTGG-3') and HCO2198 (5'-TAAACTTCAGGCTGACCAAAAAATCA-3') (Folmer et al., 1994).

DNA amplification was performed in a final volume of $25 \mu$ c containing $1 \mu \mathrm{l}$ of the extracted DNA, $1 \times$ KAPA2G Robust HotStart ReadyMix (contains $2 \mathrm{mM} \mathrm{MgCl}_{2}$ at $1 \mathrm{X}$ ) and $0.5 \mu \mathrm{M}$ of each primer. All PCRs were conducted in an Eppendorf Mastercycler $^{\circledR}$ using the following thermal profile: initial denaturation at $95^{\circ} \mathrm{C}$ for $5 \mathrm{~min}$, followed by 35 cycles of $94^{\circ} \mathrm{C}$ for $60 \mathrm{~s}, 54^{\circ} \mathrm{C}$ for $60 \mathrm{~s}, 72^{\circ} \mathrm{C}$ for $90 \mathrm{~s}$ and a final extension step at $72^{\circ} \mathrm{C}$ for $7 \mathrm{~min}$. The PCR products were purified using the QIAquick PCR Purification Kit (Qiagen) according to the manufacturer's instructions, while DNA sequencing in both directions was performed by Macrogen Inc. (Seoul, Korea).

\section{Genetic analysis}

Sequences were edited using FinchTV (www.geospiza. com). After multiple alignments, conducted using CLUSTAL W integrated in MEGA5 software (Tamura et al., 2011), sequences showed no indels (insertion/deletion) and were trimmed to a length of $630 \mathrm{bp}$. All sequences were deposited under accession numbers KC237734-KC237768 in GenBank. For calculation of average genetic distances between sequences, within each group and between groups of species, we used Kimura's two-parameter method (K2P) of base substitution. Maximum parsimony (MP) and neighbor joining (NJ) trees were also obtained using MEGA5 software. The robustness of the trees was assessed using a bootstrap analysis with 1000 replicates. A COI sequence of Aphidius rhopalosiphi De Stefani Perez from GenBank (Accession No. JN164775.1) 
Table 1. Sampling data for specimens used for molecular confirmation of species status and genetic variability study of L. orientalis.

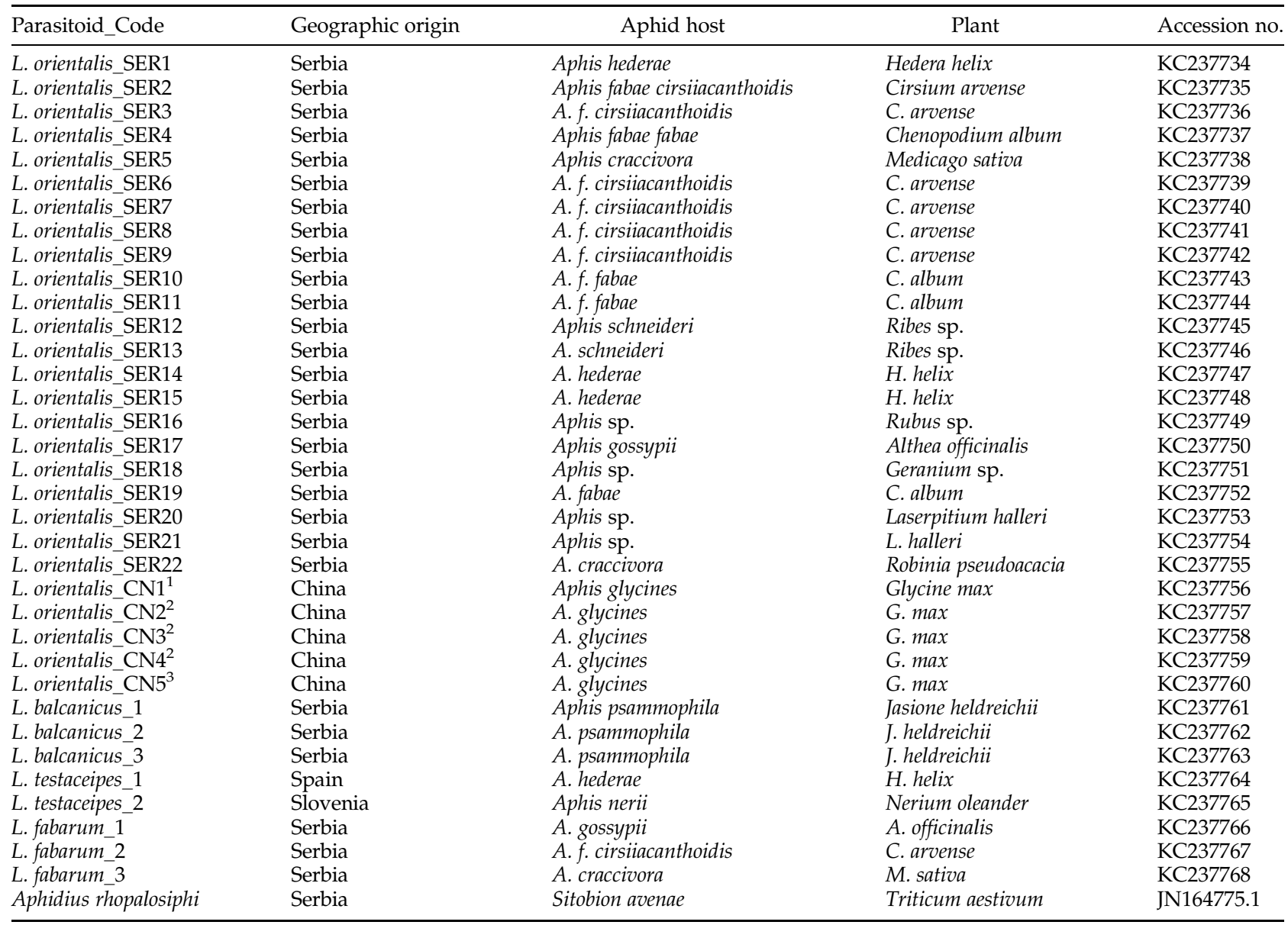

1 lab culture1 Newark USA.

2 lab culture2 Newark USA.

${ }^{3}$ lab culture3 Newark USA.

Table 2. Number of collected samples with Lysiphlebus specimens and proportion of samples with L. orientalis in Serbia for period 1995-2011. Only years in which L. orientalis was found are shown.

\begin{tabular}{lccccc}
\hline & 1995 & 2002 & 2008 & 2010 & 2011 \\
\hline No. of Lysiphlebus samples & 18 & 5 & 32 & 31 & 27 \\
No. of L. orientalis samples & $1(5.55 \%)$ & $1(20 \%)$ & $2(6.25 \%)$ & $9(29.03 \%)$ & $9(33.33 \%)$ \\
\hline
\end{tabular}

was used as an outgroup taxon for molecular phylogenetic analyses.

\section{Results}

During a nearly two-decade-long research of the Aphiidinae fauna of Serbia, specimens that are morphologically identical to $L$. orientalis were encountered very sporadically. The first record is from 1995, but finding these parasitoids only became a regular occurrence in 2010 and 2011 (table 2). In total, 214 females, but no males, were collected in two distinct regions of Serbia, the Belgrade region and northern Serbia (fig. 1). These parasitoids emerged from nine aphid hosts on 12 different host plants, forming 13 tri-trophic associations, which are summarized in the next paragraph. The lack of males is consistent with asexual reproduction as reported for $L$. orientalis in its native range. Molecular identification of the collected material as L. orientalis (see below) makes these the first records of this Far East species in Europe. Based on the number of records and diversity of aphid hosts, it appears that the Belgrade region is the center of introduction where L. orientalis gained a foothold and from where it could expand its geographic range as well as its host range. This opinion is supported by the results of a long-term research on aphid parasitoids (including Lysiphlebus) realized since 1956 in the Czech Republic (Starý, 2006) and nearby 
Table 3. Mean K2P genetic distances at COI between and within (gray fields) groups of Lysiphlebus parasitoids included in the present study.

\begin{tabular}{|c|c|c|c|c|c|}
\hline & L.orientalis_SERBIA & L.orientalis_CHINA & L. balcanicus & L. testaceipes & L. fabarum \\
\hline L. orientalis_SERBIA & $0.001(0.000-0.005)$ & & & & \\
\hline L.orientalis_CHINA & 0.008 & 0.000 & & & \\
\hline L. balcanicus & 0.040 & 0.043 & 0.000 & & \\
\hline L. fabarum & 0.068 & 0.065 & 0.074 & 0.067 & $0.004(0.002-0.006)$ \\
\hline
\end{tabular}

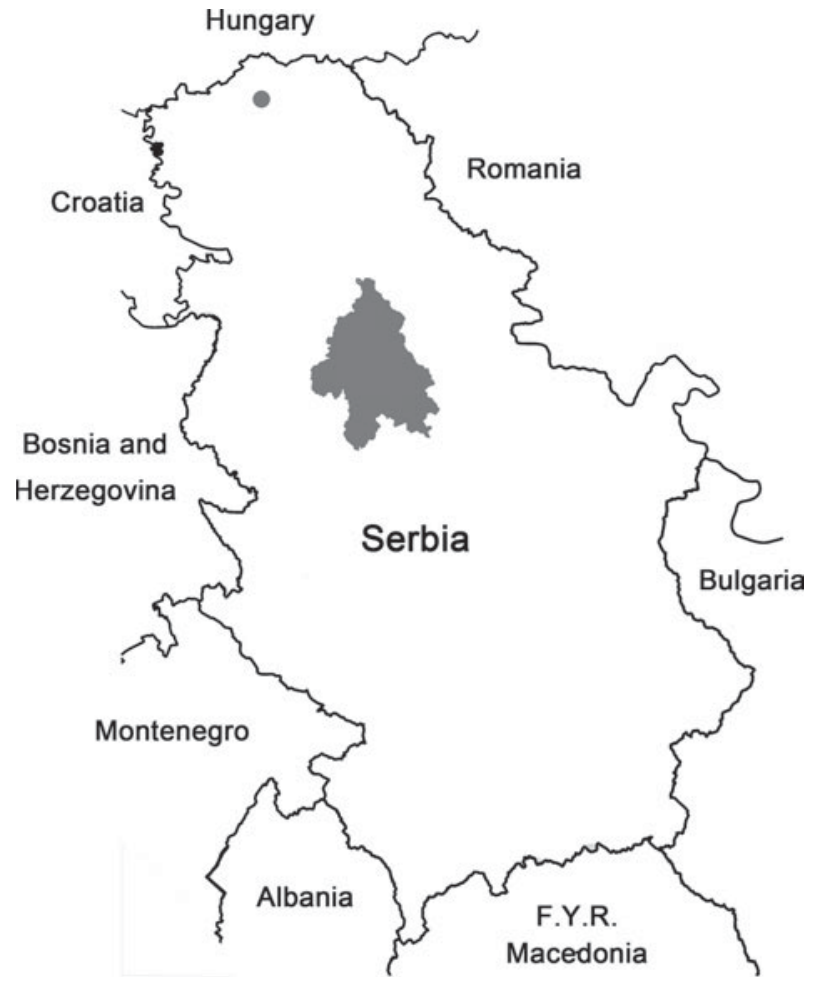

Fig. 1. Map of Serbia with marked regions where L. orientalis was detected.

Slovakia (Starý \& Lukáš, 2009). In spite of a high number of samples and reared individuals, no L. orientalis have been found in these areas.

\section{Tritrophic associations}

\section{L. orientalis Starý \& Rakhshani}

Aphis affinis Del Guercio on Mentha aquatica, Radmilovac, 12.6.1995. (10f); Aphis craccivora Koch. on Medicago sativa, New Belgrade, 13.7.2010. (5f); on Robinia pseudoacacia, Slankamen, 24.6.2011 (1f); Aphis fabae Scop. on Chenopodium album, Zemun, 7.6.2011. (28f), Slankamen, 24.6.2011. (4f); on Vicia sp., Zemun, 18.6.2010. (6f); Aphis fabae cirsiiacanthoidis Scop. on Cirsium arvense, Besni fok, 27.5.2010. (3f), Jabuka, 18.5.2008. (35f), New Belgrade, 26.5.2002. (11f), Surčin 1, 15.6.2010. (8f), Surčin 2, 15.6.2010. (1f), Surčin 3, 15.6.2010. (1f), Vrbovski, 3.6.2008. (1f); Aphis fabae fabae Scop. on C. album, Slankamen, 20.7.2010. (1f), Zemun 1, 18.6.2010. (1f), Zemun 2, 18.6.2010. (6f), Zemun 3, 18.6.2010. (21f); Aphis gossypii Glover on Althea officinalis, Zemun, 7.6.2011. (2f);
Aphis hederae Kaltenbach on Hedera helix, Zemun, 2.9.2010. (1f), Zemun, 14.6.2011. (2f); Aphis schneideri (Borner) on Ribes sp., Konjarnik, 6.6.2011. (13f); Aphis sp. on Geranium sp., Zemun, 7.6.2011. (12f); on Laserpitium halleri, Dobanovci, 17.6.2011. (2f), Zemun, 9.6.2011. (5f); on Picris hieracioides, Palić, 6.9.1995. (34f).

\section{Genetic relationships}

The identical topology of both, the MP (fig. 2) and NJ (not shown) trees, shows that specimens of L. orientalis from Serbia and China are each other's closest relatives and, with bootstrap values of $99 \%$ and $100 \%$, respectively, form one phylogenetic clade.

The calculated genetic distances (K2P) between specimens of $L$. orientalis from Serbia and China are very low with a mean distance of 0.008 (table 3).

For the COI barcoding region used here, this is within the range of intraspecific divergence observed in other species of Aphidiinae and well below the level typically found for between-species divergence (Derocles et al., 2011; Sandrock et al., 2011). Both trees further show that L. orientalis is close to other members of the 'testaceipes' group, L. testaceipes and L. balcanicus, and more distantly related to L. fabarum.

\section{Discussion}

Although Hymenoptera constitute the largest proportion (63.3\%) of alien arthropod predators and parasitoids in Europe, there are presently only five alien Aphidiinae species reported (Roy et al., 2011). All of them (Aphidius colemani Viereck, Aphidius smithi Shama \& Subba Rao, Lysiphlebus testaceipes, Pauesia cedrobii Starý \& Leclant, and Pauesia unilachni (Gahan)) were introduced as biocontol agents (Starý, 2006). Here we report the occurrence of L. orientalis in Serbia, an aphid parasitoid that is new to Europe and which has the potential to become invasive. Its arrival in Europe appears to predate the recognition of its invasion substantially and it predates its formal species description as a parasitoid of soybean aphid in China (Starý et al., 2010). The first records in Serbia are from 1995, but previous to 2010 there are only five records. These specimens were mistakenly treated as rare female morphotypes of L. fabarum. Only when the number of records of these 'morphotypes' increased at about the same time as L. orientalis was described in China did we suspect that they belong to $L$. orientalis. This suspicion is now confirmed by our analyses of COI sequences. The introduction of a parasitoid attacking agricultural pests such as aphids may not appear undesirable at first glance. However, new aphid parasitoids can become invasive by replacing native parasitoid species, as documented for L. testaceipes (EPPO 2008-0326/28). Important determinants of their potential impact are host range and reproductive mode. L. orientalis is thought to 


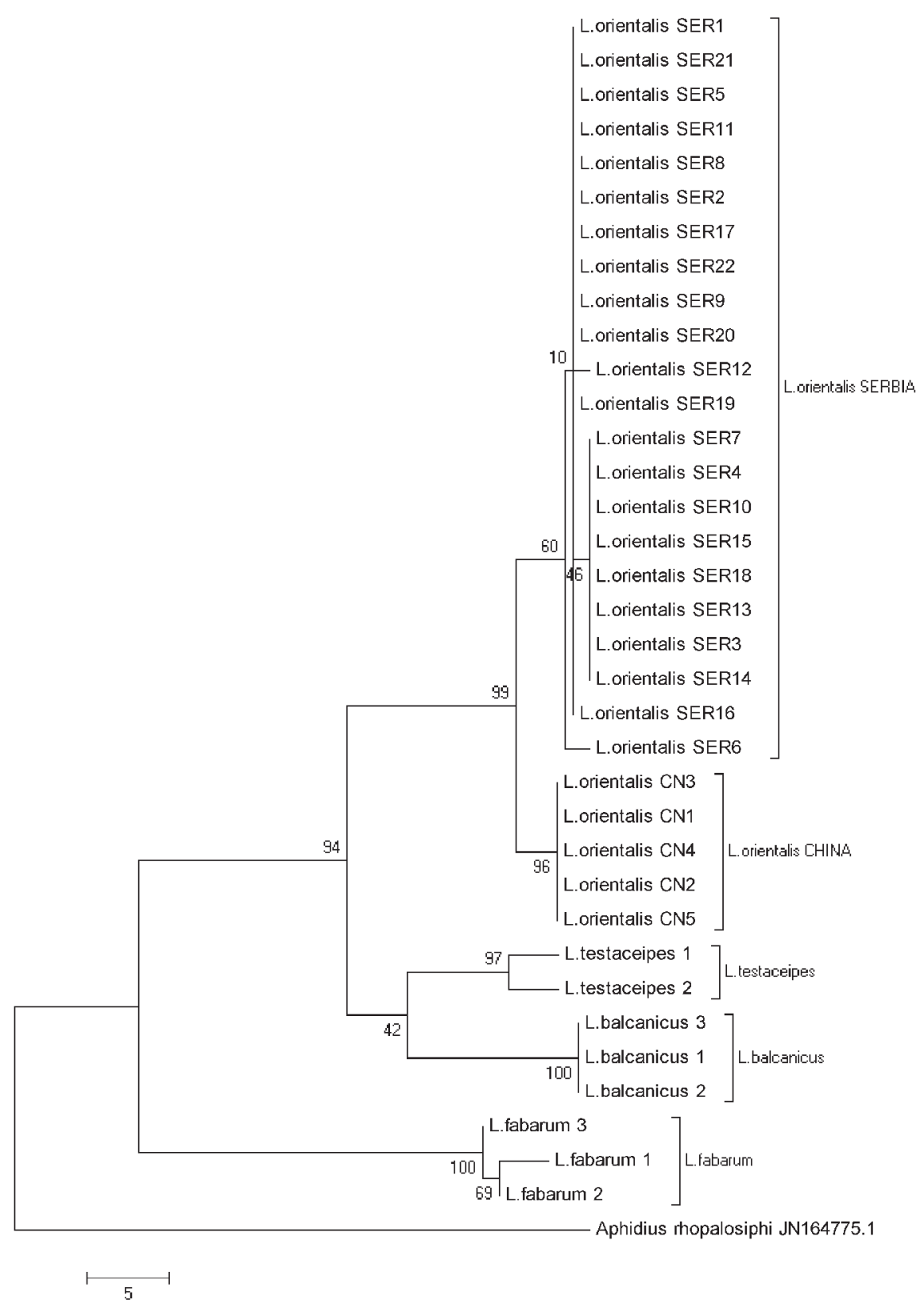

Fig. 2. The first out of the 438 most parsimonious trees (length=126) for COI of Lysiphlebus specimens. A. rhopalosiphi was used as the outgroup species. Numbers above/below the branches represent the bootstrap values (\%).

be monophagous on A. glycines in China (Starý et al., 2010), but in Serbia it parasitizes several species of the genus Aphis. Based on the limited data available so far, its host range overlaps strongly with that of L. fabarum, which is the most abundant native parasitoid on hosts of the genus Aphis, providing an important ecosystem service through its impact on pest aphid populations (Starý, 2006). L. orientalis also shares its mode of reproduction with $L$. fabarum. Based on the complete absence of males we concluded that L. orientalis in Europe reproduces by thelytokous parthenogenesis, as in its place of origin (Starý et al., 2010). This mode of reproduction clearly facilitates invasion, because a single female is sufficient to form a new population, and it can make exotic species more competitive because they forego the cost of producing males (Maynard Smith, 1978), resulting in a higher rate of population increase.

Kaiser \& Heimpel (2011) described another phenomenon that makes $L$. orientalis a potentially problematic invader. L. orientalis preferentially attacks older aphids (A. glycines) that are mature enough to reproduce before being killed by the parasitoid larva. Furthermore, offspring of parasitized A. glycines reproduce earlier and faster than offspring of unparasitized $A$. glycines. These are undesirable attributes from a pest control perspective as they allow the host aphids to maintain high numbers despite high rates of parasitism 
(Kaiser \& Heimpel, 2011). As yet there are no investigations of such phenomena in Serbian populations of L. orientalis. If present, they could have significant implications for the structure of plant-aphid-parasitoid food webs in agroecosystems. For example, L. orientalis may become a serious competitor of $L$. fabarum, but not have equivalent effects on aphid population densities.

L. orientalis is indubitably established in Serbia since it is has been present in the same area for at least 17 years, but it appears to still be restricted to ruderal vegetation in urban areas. This is consistent with the community maturity concept of Shea \& Chesson (2002), which states that man-made environments have high levels of niche opportunities for alien species, because such communities have had less time to assemble, and less time for their constituent species to adapt to the local conditions. Their species might also have lower competitive abilities than those in mature communities (Shea \& Chesson, 2002). The occurrence of L. testaceipes in the Mediterranean also manifests similar occurrence patterns (Starý et al., 1988, 2004). The expansion of host range observed during the past two years and the increase in population density suggest that L. orientalis is moving past the lag phase of population growth in Serbia. The reasons mentioned above suggest that $L$. orientalis has a great potential to become a problematic invasive parasitoid in Europe. Constant monitoring is therefore necessary, as well as further research on its distribution, biology and ecology.

The pathways of introduction of $L$. orientalis are still unknown, but some conjectures can be made. Over the past two decades, a very intensive official and unofficial trade of goods has developed between China and Serbia. New exotic species could thus be introduced together with imported soybean, for example. Belgrade as the capital of Serbia is under the biggest pressure of immigration and trade, and is therefore the most likely center of exotic species introductions. To date Serbia is the only European country in which L. orientalis has been detected, despite the fact that the Aphidiine fauna is extensively investigated also in other parts of Europe (Kavallieratos et al., 2004; Starý, 2006; Starý \& Lukáš, 2009). Considering the level of trade and transfers between western European countries and China, it is possible that $L$. orientalis is already present but still undetected elsewhere in Europe.

\section{Acknowledgments}

We would like to thank Professor George Heimpel (University of Minnesota) for the loan of specimens of L. orientalis from China. This study was supported by the SCOPES program of the Swiss National Science Foundation (Grant No. IZ73Z0_1 28174) and the Ministry of Education and Science of the Republic of Serbia (43001). The work by P. Starý was partially funded from the Entomology Institute Grant No. AV0Z50070508 (Academy of Sciences of the Czech Republic).

\section{References}

Boivin, G., Hance, T. \& Brodeur, J. (2012) Aphid parasitoids in biological control. Canadian Journal of Plant Science 92, 1-12.

Brewer, M.J. \& Elliott, N.C. (2004) Biological control of cereal aphids in North America and mediating effects of host plant and habitat manipulations. Annual Review of Entomology 49, 219-242.
Cecilio, A. (1994) Faunistic evolution after the introduction of Lysiphlebus testaceipes (Cresson) (Hymenoptera: Aphidiidae) in Portugal, and its importance for the control of aphids. Boletin de Sanidad Vegetal Plagas 20, 471-476.

Derocles, S.A., LE Ralec, A., Plantegenest, M., Chaubet, B., Cruaud, C., Cruaud, A. \& Rasplus, J.Y. (2011) Identification of molecular markers for DNA barcoding in the Aphidiinae (Hym. Braconidae). Molecular Ecology Resources 12, 197-208.

Folmer, O., Black, M., Hoeh, W., Lutz, R. \& Vrijenhoek, R. (1994) DNA primers for amplification of mitochondrial cytochrome c oxidase subunit I from diverse metazoan invertebrates. Molecular Marine Biology and Biotechnology 3, 294-297.

Hagvar, E.B. \& Hofsvang, T. (1991) Aphid parasitoids (Hymenoptera: Aphidiidae): biology, host selection and use in biological control. Biocontrol News and Information 12, 13-41.

Hallman, G.J. \& Schwalbe, C.P. (2002) Invasive Arthropods in Agriculture: Problems and Solutions. Enfield, NH, USA, Science Publishers Inc.

Heimpel, G.E., Frelich, L.E., Landis, D.A., Hopper, K.R., Hoelmer, K.A., Sezen, Z., Asplen, M.K. \& Wu, K. (2010) European buckthorn and Asian soybean aphid as components of an extensive invasional meltdown in North America. Biological Invasions 12, 2913-2931.

Kaiser, M.C. \& Heimpel, G.E. (2011) Unexpected risk: how parasitoid induced maternal effects may upset biological control. In Proceedings of the Meeting of Entomological Society of America, North Central Branch, March 13-16, 2011, Minneapolis, MN, Entomological Society of America. Available online at http: / / www.ncb2011.umn.edu/ (accessed 30 June 2012).

Kambhampati, S., Voelkl, W. \& Mackauer, M. (2000) Phylogenetic relationships among genera of Aphidiinae (Hymenoptera: Braconidae) based on DNA sequence of the mitochondrial 16S rRNA gene. Systematic Entomology 25, 437-445.

Kavallieratos, N.G., Tomanović, Ž., Starý, P., Athanassiou, C.G., Sarlis, G.P., Petrović, O., Niketić, M. \& Veroniki, M.A. (2004) A survey of aphid parasitoids (Hymenoptera: Braconidae: Aphidiinae) of southeastern Europe and their aphid-plant associations. Applied Entomology and Zoology 39, 527-563.

Mackauer, M. (1961) Die Typen der Unterfamilie Aphidiinae des Britischen Museums London (Hymenoptera: Braconidae). Beitraege zur Entomologie 11, 96-154.

Maynard Smith, M.J. (1978) The Evolution of Sex. Cambridge, Cambridge University Press.

Nyabuga, F.N., Loxdale, H.D., Sharbel, T.F., Todd, M. \& Weisser, W.W. (2009) Microsatellites from Lysiphlebus hirticornis Mackauer (Hymenoptera: Braconidae), a specialist primary parasitoid attacking the specialist tansy aphid, Metopeurum fuscoviride Stroyan (Hemiptera: Aphididae). Molecular Ecology Resources 9, 931-934.

Petrović, A., Tomanović, Ž., Žikić, V., Kavallieratos, N.G. \& Starý, P. (2009) New records of Aphidiinae (Hymenoptera: Braconidae) from Serbia and Montenegro. Acta Entomolgica Serbica 14, 219-224.

Petrović, A., Žikić, V., Petrović-Obradović, O., Mitrovski Bogdanović, A., Kavallieratos, N.G., Starý, P. \& Tomanović, Ž. (2011) Two new species of aphid parasitoids (Hymenoptera, Braconidae, Aphidiinae) from the Balkan Peninsula. Zootaxa 2895, 58-64.

Pike, K., Starý, P., Miller, T., Graf, G., Allison, D., Boydston, L. \& Miller, R. (2000) Aphid parasitoids (Hymenoptera: Braconidae: Aphidiinae) of Northwest USA. Proceedings of the Entomological Society of Washington 102, 699-740. 
Ragsdale, D.W., Landis, D.A., Brodeur, J., Heimpel, G.E. \& Desneux, N. (2011) Ecology and management of the soybean aphid in North America. Annual Review of Entomology 56, 375-399.

Roy, H.E., Roy, D.B. \& Roques, A. (2011) Inventory of terrestrial alien arthropod predators and parasites established in Europe. BioControl 56, 477-504.

Sandrock, C., Schirrmeister, B. \& Vorburger, C. (2011) Evolution of reproductive mode variation and host associations in a sexual-asexual complex of aphid parasitoids. BMC Evolutionary Biology 11, 348. doi:10.1186/1471-2148-11-348.

Shea, K. \& Chesson, P. (2002) Community ecology theory as a framework for biological invasions. Trends in Ecology $\mathcal{E}$ Evolution 17, 170-176.

Starý, P. (2006) Aphid parasitoids of the Czech Republic (Hymenoptera: Braconidae: Aphidiinae). Praha, Czech Republic, Academia.

Starý, P. \& Lukáš, J. (2009) Aphid parasitoids and their tritrophic associations in Slovakia (Hymenoptera: Braconidae, Aphidiinae). Acta Hymenopterologica Slovaca 1, 1-63.

Starý, P., Lyon, J.P. \& Leclant, F. (1988) Post-colonisation host range of Lysiphlebus testaceipes (Cresson) in the mediterranean area (Hymenoptera, Aphidiidae). Acta Entomologica Bohemoslovaca $85,1-11$.

Starý, P., Lumbierres, B. \& Pons, X. (2004) Opportunistic changes in the host range of Lysiphlebus testaceipes (Cr.), an exotic aphid parasitoid expanding in the Iberian Peninsula. Journal of Pest Science 77, 139-144.

Starý, P., Rakhshani, E., Tomanović, Ž., Hoelmer, K., Kavallieratos, N.G., Yu, J., Wang, M. \& Heimpel, G.E. (2010) A new species of Lysiphlebus Förster 1862 (Hymenoptera: Braconidae: Aphidiinae) attacking soybean aphid, Aphis glycines Matsumura (Hemiptera: Aphididae) from China. Journal of Hymenoptera research 19, 179-186.

Tamura, K., Peterson, D., Peterson, N., Stecher, G., Nei, M. \& Kumar, S. (2011) MEGA5: molecular evolutionary genetics analysis using maximum likelihood, evolutionary distance, and maximum parsimony methods. Molecular Biology and Evolution 28, 2731-2739.

van Achterberg, C. (2011) Fauna Europaea: Hymenoptera: Braconidae. Fauna Europaea version 2.4. Available online at http://www.faunaeur.org/ (accessed 29 June 2012). 